\title{
The N-terminal region of the Saccharomyces cerevisiae RasGEF Cdc25 is required for nutrient- dependent cell-size regulation
}

\author{
Correspondence \\ Enzo Martegani \\ enzo.martegani@unimib.it
}

Received 10 November 2005

Revised 20 December 2005

Accepted 6 January 2006

\author{
Fiorella Belotti, Renata Tisi and Enzo Martegani
}

\author{
Department of Biotechnology and Biosciences, University of Milano-Bicocca, Piazza della \\ Scienza 2, 20126 Milan, Italy
}

\section{INTRODUCTION}

In the budding yeast Saccharomyces cerevisiae, the Cdc25/ Ras/cAMP signal transduction pathway regulates many cellular and physiological processes, such as growth, resting state and sporulation (reviewed by Thevelein \& de Winde, 1999; Thevelein et al., 2000), carbohydrate and nitrogen metabolism, stress tolerance, and cell wall resistance to lyticase digestion (Martegani et al., 1984; Plesset et al., 1987; Van Dijck et al., 1995). The cAMP pathway is involved in the control of cell cycle progression at $G_{0} / G_{1}$ and/or $G_{2}$ phases (Drebot et al., 1990; Thevelein, 1992, Anghileri et al., 1999), Cln3 $\mathrm{G}_{1}$ cyclin translation (Barbet et al., 1996; Hall et al., 1998; Polymenis \& Schmidt, 1997), and nutritional modulation of the critical cell size required for entry into the $S$ phase (Baroni et al., 1989; Mitsuzawa, 1994).

In yeast, cyclic AMP is synthesized by adenylate cyclase, which is encoded by the CYR1/CDC35 gene, and degraded

Abbreviations: $\mathrm{BI}$, budding index; $\mathrm{CDB}$, cyclin destruction box; FACS fluorescence-activated cell sorting; GEF, guanine nucleotide exchange factor; $\mathrm{PI}$, propidium iodide; $\mathrm{PKA}$, protein kinase $\mathrm{A} ; P_{\mathrm{s}}$, protein content at entry into S-phase; $P_{t}$, total protein content. by Pde1 and Pde2 phosphodiesterases (Ma et al., 1999). Yeast adenylate cyclase is activated by two different systems: the G-protein-coupled receptor system, acting through the G-protein Gpa2 (Nakafuku et al., 1988; Colombo et al., 1998), and the Cdc25/Ras system (Toda et al., 1985). The $\mathrm{Gpa} 2$ protein is closely related to the extracellular glucose receptor Gpr1, and it seems to be mainly involved in producing the rapid increase of cAMP levels that occurs upon addition of high glucose concentrations $(100 \mathrm{mM})$ to glucose-derepressed cells. Cdc25 and Ras are also required for the glucose- (and fructose-) induced cAMP increase (Rolland et al., 2000); they are essential for cell viability, and play a central role in adenylate cyclase activity regulation during yeast growth (Tamanoi, 1988).

Activity of Ras proteins is modulated by their ability to switch between an inactive state, when bound to GDP, and an active state, when associated with GTP. The ratio of GDP/ GTP on Ras proteins is controlled by the guanine nucleotide exchange factors (GEFs) Cdc25 (Jones et al., 1991) and Sdc25 (Damak et al., 1991; Boy-Marcotte et al., 1996), which stimulate the GDP-GTP exchange on Ras, and by the Ira1 and Ira2 proteins, which promote intrinsic Ras GTPase activity (Tanaka et al., 1989, 1990a, b). 
The S. cerevisiae Cdc25 protein was the first RasGEF to be identified (Camonis et al., 1986; Martegani et al., 1986). Cdc25 is responsible for Ras1 and Ras2 activation, and is required for the glucose-induced rapid increase of Ras2GTP levels (Rudoni et al., 2001; Colombo et al., 2004), and the activation of adenylate cyclase (Engelberg et al., 1990); however, the molecular basis of the mechanism that regulates the exchange activity of $\mathrm{Cdc} 25$ in response to nutrients is yet to be elucidated.

The yeast $C D C 25$ gene encodes a 1589 aa protein that is produced as a polypeptide of about $180 \mathrm{kDa}$ (Vanoni et al., 1990; Jones et al., 1991; Gross et al., 1992). The C-terminal fragment (aa 1256-1589), containing the GEF domain, is essential for normal growth and viability of $c d c 25 \Delta$ and cdc25 ts mutants (Lai et al., 1993; Coccetti et al., 1995).

In the large $\mathrm{N}$-terminal region of $\mathrm{Cdc} 25$ (aa residues 1-1101), there is an SH3 motif (aa 60-130) that binds adenylate cyclase, and seems to enhance its responsiveness to activation by Ras in vitro (Mintzer \& Field, 1999). Next to the $\mathrm{SH} 3$ motif, there is a cyclin destruction box (CDB) motif, and the $\mathrm{Cdc} 25$ protein content in the yeast cell is controlled by a ubiquitin-dependent degradation process specifically driven by this CDB motif (Kaplon \& Jacquet, 1995).

A possible biological function for the large Cdc25 Nterminus has been suggested as a result of the finding that upon glucose stimulation in yeast, some residues within aa 114-348 become phosphorylated, leading to decreased association of Cdc25 with the membranes and accessibility to Ras (Gross et al., 1992). This phosphorylation is believed to be part of a negative-feedback loop resulting from the action of cAMP-dependent protein kinase A (PKA).

The Cdc25 N-terminus has been suggested to have weak dominant-negative properties, which inhibit the function of the whole Cdc25 protein in vivo, possibly by interacting with the complete endogenous Cdc25, thus interfering with its ability to activate Ras (Chen et al., 2000).
To better characterize the function of the $\mathrm{N}$-terminal region of the RasGEF protein, two yeast mutants that lacked most of the Cdc25 N-terminal domain were constructed. In addition, we made two other mutants in which the whole CDC25 gene was replaced by a catalytic domain from a heterologous mammalian RasGEF: the mouse RasGRF1/ $\mathrm{Cdc} 25^{\mathrm{Mm}}$ or the human Sos1 (Martegani et al., 1992; Gross et al., 1999). Since the homology between S. cerevisiae Cdc25 and mammalian GEFs is restricted to the Ras-exchange domain, and is not very high (about $30 \%$ similarity), it was thought that the latter two mutants would help to clarify whether some regions close to or inside the Cdc25 exchange domain are also responsible for some regulation. Finally, the effect of overproduction of different fragments of the Cdc25 N-terminus was tested in the wild-type strain, and in different mutant backgrounds.

Here, we show that lack of the N-terminal region of Cdc25, or the presence of an unregulated heterologous GEF activity, causes a defect in the nutrient modulation of cell size and cell cycle regulation.

\section{METHODS}

Strains, plasmids and growth conditions. S. cerevisiae haploid strains used in this work are described in Table 1. Deletion mutants were generated in the diploid W303 strain (Thomas \& Rothstein, 1989), using plasmid-derived gene replacement cassettes. The cassettes were prepared in a pGEM3z (with the SalI site disrupted) vector (Promega) by insertion of the URA3 marker and the CDC25 gene flanking regions, which were extracted from plasmid pCDC25(LEU2)-2 (Broek et al., 1987). Briefly, first, the SmaI-NdeI (filled-in) fragment from plasmid pVT-102U (Vernet et al., 1987) was inserted into the BamHI (filled-in)-HincII sites; then, the BamHI (filled-in)-HincII fragment, spanning the $5^{\prime}$ CDC25 flanking region (bp positions -837 to -314 ), was inserted in the HindIII (filled-in) site, upstream of the URA3 marker; finally, the SphI-excised fragment, spanning the $3^{\prime}$ CDC25 flanking region (bp positions +4653 to +5230 ), was inserted into the SmaI site, downstream of the marker. The cassettes used to generate the $\mathrm{W} \Delta \mathrm{Cdc} 25^{\mathrm{Mm}}$ and $\mathrm{W} \Delta \mathrm{hSos} 1$ strains were excised by SphI cutting from the pVTUCdc25 ${ }^{\mathrm{Mm}}$ (Coccetti et al., 1995) and pVTU-hSos1 (M. Vanoni,

Table 1. Strains used in this study

\begin{tabular}{|c|c|c|}
\hline Strain & Genotype & Reference \\
\hline W303 & MATa ade2-1 can1-100 his3-112 trp1-1 ura3-1 & Thomas \& Rothstein (1989) \\
\hline Diploid W303 & MATa/ $\alpha$ ade2-1/ade2-1 can1-100/can1-100 his3-112/his3-112 trp1-1/trp1-1 ura3-1/ura3-1 & Thomas \& Rothstein (1989) \\
\hline $\mathrm{W} \Delta \mathrm{N} 1$ & 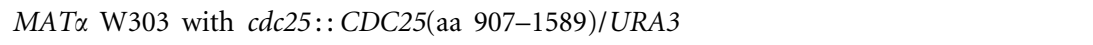 & This work \\
\hline $\mathrm{W} \Delta \mathrm{N} 2$ & MATa W303 with $c d c 25::$ CDC25(aa 1147-1589)/URA3 & This work \\
\hline $\mathrm{W} \Delta \mathrm{Cdc} 25^{\mathrm{Mm}}$ & MAT $\alpha$ W303 with $c d c 25:: A D H p r o m-C d c 25^{\mathrm{Mm}}$ (aa 976-1262)/URA3 & This work \\
\hline W $\Delta$ hSos 1 & MAT $\alpha$ W303 with cdc25::ADHprom-hSos1(aa 549-1333)/URA3 & This work \\
\hline RT11 & W303-1A with pYX212-CDC25(aa 1-875) & This work \\
\hline RT12 & W303-1A with pYX212-CDC25(aa 1-1100) & This work \\
\hline RT13 & W303-1A with pYX212-CDC25(aa 353-1100) & This work \\
\hline RT14 & W303-1A with pYX212-CDC25(aa 876-1100) & This work \\
\hline RT15 & W303-1A with pYX212-CDC25(aa 353-875) & This work \\
\hline RT16 & W303-1A with pYX212-CDC25(aa 1-352) & This work \\
\hline
\end{tabular}


Università di Milano-Bicocca, Milan, Italy) plasmids, respectively, which encode aa $976-1262$ of Cdc2 $5^{\mathrm{Mm}}$, and aa $549-1333$ of hSos1, respectively, and inserting into the SphI site, between the 5' CDC25 flanking region and the URA3 marker. To generate the $\mathrm{N}$-terminal deleted strains, deleted ORFs were prepared by PCR using the oligonucleotides GGTCGGGATCCAGATTGCAG, and either GAAGATCTGATACAACTATCCAATATCCAC (for the 1-2628 deletion, leading to the generation of a new ORF, starting from the first following ATG, and encoding aa 907-1589) or GTATCCCATGGGATACAACTATCCAATATCCAC (for the 1-3304 deletion, creating a new ORF encoding aa 1147-1589), to amplify the CDC25 promoter, and then to substitute the SalI to the BglII or the NcoI CDC25 gene fragment, respectively. The newly generated ORF was then inserted instead of the $5^{\prime}$ flanking region in the pGEM3z gene replacement cassette. The cassettes were finally excised by restriction, or amplified by PCR to transform the diploid W303 strain. Gene replacement was verified by PCR in the heterozygote diploids, and haploid mutant strains were recovered by spore dissection.

Plasmid pYX212-CDC25(aa 1-875) was prepared by inserting into the BamHI site of pYX212 (Novagen) the 3000 bp fragment obtained by BamHI-BglII partial digestion (containing nt 1-2628 of CDC25 ORF) of the HindIII fragment of the CDC25 gene, previously subcloned in the HindIII site of the same plasmid. Plasmid pYX212-CDC25(aa 1-1100) was obtained by inserting into the NcoI site of pYX212 the $3700 \mathrm{bp}$ fragment obtained by NcoI digestion (spanning nt 1-3304 of CDC25 ORF) from the same CDC25-HindIII-fragment-containing plasmid. Plasmid pYX212-CDC25(aa 353-1100) and plasmid pYX212CDC25(aa 876-1100) were prepared by subcloning into the BamHI site of pYX212 either the $2200 \mathrm{bp}$ fragment obtained by BamHI-BglII partial digestion from pYX212-CDC25(aa 1-1100) or the $680 \mathrm{bp}$ fragment obtained by BglII-BamHI digestion from pYX212-CDC25(aa 1-1100). Plasmid pYX212-CDC25(aa 353-875) was obtained by deleting the BamHI-BglII fragment in pYX212-CDC25(aa 1-875). Plasmid pYX212-CDC25(aa 1-352) was prepared by inserting the $1400 \mathrm{bp}$ fragment obtained by BamHI-BglII digestion from pYX212-CDC25(aa 1-1100).

Rich (YEP) medium contained $1 \%$ yeast extract and $2 \%$ peptone (Biolife), and was supplemented with $2 \%$ glucose (YPD), $2 \%$ ethanol (YPE), $2 \%$ raffinose, $2 \%$ potassium acetate or $2 \%$ glycerol as the

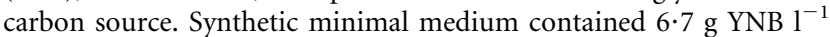
(Difco) and $50 \mathrm{mg} \mathrm{l}^{-1}$ of the appropriate auxotrophic requirements, and was supplemented with a carbon source, as for YEP medium. For the trehalase assay, $2 \%$ glycerol and $0.01 \%$ glucose were added to YEP medium. Nitrogen starvation experiments were performed using synthetic medium containing $1.7 \mathrm{~g} \mathrm{YNB}^{-1}$ (without amino acids and ammonium sulfate) and $5 \mathrm{mg} \mathrm{l}^{-1}$ of the appropriate auxotrophic requirements, and supplemented with $2 \%$ glucose.

The cell density of liquid cultures grown at $24^{\circ} \mathrm{C}$ was determined with a Coulter Counter (model Z2; Beckman Coulter) on mildly sonicated, diluted samples. The specific growth rate $(\mu)$ was determined by plotting the increase of cell number against time, and duplication time $\left(t_{\mathrm{d}}\right)$ was subsequently calculated according to the equation $t_{\mathrm{d}}=\ln 2 / \mu$. Budding index (BI) was determined by direct microscopic count of at least 300 cells that had been mildly sonicated, and fixed in $4 \%$ formalin (Vanoni et al., 1983). Cell volume distribution was determined with a Coulter Counter Channelyzer 256, as described (Baroni et al., 1989).

During nutritional shift-up from ethanol to glucose, $2 \%$ glucose was added to cells growing exponentially in ethanol at time $t=0$; growth was monitored by plotting both the cell number and the BI against time.

Flow cytofluorimetric analysis. A total of $2 \times 10^{7}$ exponentially growing cells was collected by filtration for each sample, fixed in $70 \%$ ethanol, stored at $4{ }^{\circ} \mathrm{C}$, and subsequently processed for fluorescenceactivated cell sorting (FACS) analysis using a Becton Dickinson FACStarPlus equipped with a Coherent Innova 70 Argon Ion laser (488 nm emission). DNA, protein and double-parameter analyses (DNA and protein analyses on the same sample) were performed as described previously (Coccetti et al., 2004). Cell size was operationally defined as the mean protein content determined by flow cytometry in the channel of FITC fluorescence of FITC-stained cells (Baroni et al., 1989). Protein content at the onset of DNA replication $\left(P_{\mathrm{s}}\right)$ was determined as the mean protein content of properly gated early S-phase cells obtained from the density plot derived by FACS analysis of double propidium iodide (PI)/FITC stained cells (Coccetti et al., 2004). Plot generation, analysis and gating process were performed with WinMDI 2.8 software (downloaded from the TSRI Cytometry software page at http://facs.scripps.edu/software.html).

Heat-shock sensitivity assay. For the heat-shock sensitivity assay in liquid medium, cells were grown in complete or selective medium containing $2 \%$ glucose at $30^{\circ} \mathrm{C}$ to mid-exponential growth phase $\left(5 \times 10^{6}\right.$ cells ml $\left.^{-1}\right)$, then diluted in fresh medium to a concentration of $2 \cdot 5 \times 10^{6}$ cells $\mathrm{ml}^{-1}$. Cells were then exposed to $51^{\circ} \mathrm{C}$ for the indicated time $(\mathrm{min})$, and then $10^{4}$ cells were spotted onto complete or selective medium, and incubated at $30^{\circ} \mathrm{C}$ for 2 days.

For the heat-shock sensitivity assay on ira $1 \Delta$ strains, cells were grown on selective medium for 2 days, then exposed to $51{ }^{\circ} \mathrm{C}$ for $17 \mathrm{~min}$, replica plated on fresh medium, and incubated at $30^{\circ} \mathrm{C}$ for 2 days.

Trehalase activity assay. Yeast cells were grown in glycerolcontaining YEP medium at $30^{\circ} \mathrm{C}$ until they reached the exponential growth phase $\left(\mathrm{OD}_{600} 0 \cdot 5-1\right)$. The cells were then collected by centrifugation, washed once in ice-cold water, and resuspended in $50 \mathrm{mM}$ MES buffer $(\mathrm{pH} 7 \cdot 5)$ containing $50 \mu \mathrm{M} \mathrm{CaCl}$. Samples were collected after incubation for $30 \mathrm{~min}$ at $30^{\circ} \mathrm{C}$.

Extracts were prepared by shaking with glass beads for $90 \mathrm{~s}$, followed by a centrifugation step $\left(5 \mathrm{~min}, 13000 \mathrm{~g}, 4^{\circ} \mathrm{C}\right.$ ), then dialysed overnight at $4^{\circ} \mathrm{C}$ in $10 \mathrm{mM}$ MES buffer (pH 7.5) containing $50 \mu \mathrm{M} \mathrm{CaCl}_{2}$, using a $\mathrm{BRL}$ microdialysis system. Protein concentration was determined using the Lowry method. Trehalase activity was assayed in the cell extract, as described by Wera et al. (1999), and expressed as units, where $1 \mathrm{U}$ is the activity that produces $1 \mathrm{nmol}$ glucose $\mathrm{min}^{-1}$.

\section{RESULTS}

\section{cdc25 deletion mutants show no growth defects except for delays in the recovery of growth and spore germination}

Different mutants were created by modifying the CDC25 locus, as described in Methods. The $\mathrm{N}$-terminal domain was deleted from the CDC25 locus in two different mutants, one with a shorter (aa 1-906) deletion, and the other with a longer (aa 1-1146) deletion. In other mutants, the entire CDC25 ORF was deleted, and substituted with an expression cassette containing the Ras-exchange domain of mammalian GEF RasGRF1/Cdc $25^{\mathrm{Mm}}$ or human Sos1; the production of either of these mammalian RasGEF domains is able to rescue the growth defect of a temperature-sensitive $c d c 25$ mutant (Martegani et al., 1992; Gross et al., 1999), and the lethality caused by $C D C 25$ deletion. The modified alleles were introduced in the diploid W303 strain, and the mutant haploid strains were recovered after tetrad dissection. 
(a)

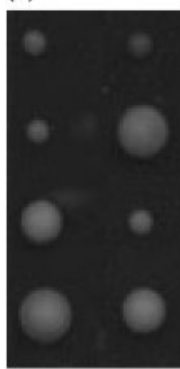

$\mathrm{W} \Delta \mathrm{N} 1$

(b)

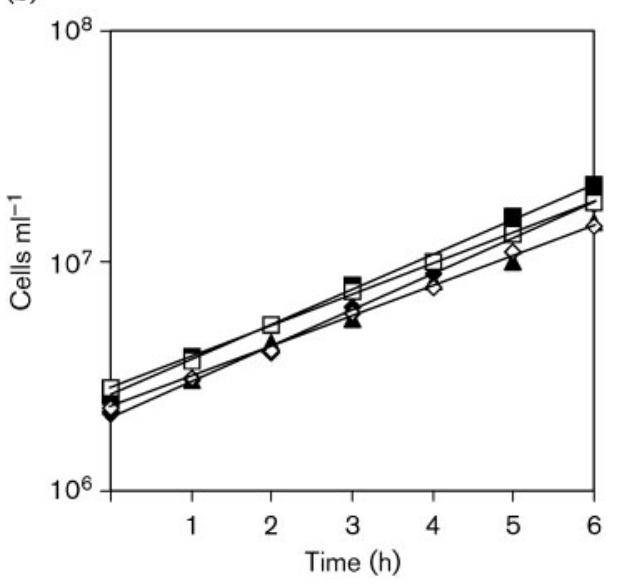

Fig. 1. Tetrad analysis and growth kinetics of the mutant strains. (a) Tetrads obtained from the dissection of mutant diploid strains showed a segregation ratio of $2: 2$, small versus large colonies. Tetrads were dissected, and incubated on YPD agar for 3 days. The figure shows representative tetrads obtained from the heterozygote strains indicated. (b) The mutant strains grew in YPD medium at a rate comparable to that of the wild-type strain. Cells were inoculated in YPD medium at $24^{\circ} \mathrm{C}$, and grown to early exponential phase. Cell density was plotted against time. Strains: W303 ( $), \mathrm{W} \Delta \mathrm{N} 1$ $(\boldsymbol{\square}), \mathrm{W} \Delta \mathrm{N} 2(\boldsymbol{\Delta}), \mathrm{W} \Delta \mathrm{Cdc} 25^{\mathrm{Mm}}(\diamond), \mathrm{W} \Delta \mathrm{hSos} 1(\square)$.

The dissections of the tetrads from all of the heterozygous diploid strains containing a mutated CDC25 allele presented a segregation pattern 2:2 (large: small colonies), and the mutant genotype, determined by PCR analysis of the colonies, always co-segregated with the small colony size (Fig. 1a). The small size of the mutant colonies was not due to a growth defect: all the mutant strains grew well, with doubling times comparable with that of the wild-type strain, not only in YPD medium (Fig. 1b), but in all the conditions tested (Table 2), including synthetic minimal medium supplemented with acetate, glycerol or ethanol as the carbon source (data not shown). Rather, it was thought that the small colony size was due to a delay in spore germination. However, all the mutant strains, except, surprisingly, $\mathrm{W} \Delta \mathrm{N} 2$, showed only a short delay in recovery of growth from stationary phase (Fig. 2), and a little longer in recovery from nitrogen starvation (data not shown). Therefore, it is probable that normally regulated Cdc25 activity is critical in the transition from the $\mathrm{G}_{0}$ phase to entry into the cell cycle. All the mutant strains were able to enter stationary phase normally, at least in YPD medium, with a high fraction of unbudded cells (up to $90 \%$ ), as shown in Fig. 2.

\section{Different cdc25 mutants show defects in nutrient-dependent cell size modulation}

As shown above, mutant strains had similar growth rates to the wild-type (Table 2), and they were able to arrest normally, mostly as unbudded cells, when grown to saturation on YPD medium, or starved of nitrogen (data not shown). Nonetheless, they showed some abnormal features during exponential growth on different carbon sources: compared with the wild type, the $\mathrm{W} \Delta \mathrm{N} 1$ strain always had a larger cell volume (Fig. 3), and a higher percentage of budded cells. In contrast, $\mathrm{W} \Delta \mathrm{N} 2$ (Fig. 3 ), $\mathrm{W} \Delta \mathrm{Cdc} 25^{\mathrm{Mm}}$ and $\mathrm{W} \Delta \mathrm{hSos} 1$ (data not shown) showed a smaller cell volume than the wild type; these mutant strains also showed a reduction in BI (Table 2). To better characterize the alterations in cell size and cell cycle regulation, we used flow cytometry to analyse the protein and DNA distributions in the wild-type and mutant strains during the exponential growth, using glucose and ethanol as carbon sources.

Protein distribution was determined (Baroni et al., 1989), and it was compared with the glucose-grown wild-type strain W303 (Fig. 4a). The mean total protein content $\left(P_{\mathrm{t}}\right)$, calculated from the protein distribution, was different in the mutant strains compared with the wild-type, in all the conditions tested; compared with the wild type, W $\Delta \mathrm{N} 1$

Table 2. Growth parameters of cdc25 mutant strains at $24^{\circ} \mathrm{C}$

$t_{\mathrm{d}}$, duplication time (h); BI, budding index (\%). SM, synthetic minimal medium supplemented with glucose.

\begin{tabular}{|c|c|c|c|c|c|c|c|c|c|c|}
\hline \multirow[t]{2}{*}{ Medium } & \multicolumn{2}{|c|}{ W303 } & \multicolumn{2}{|c|}{$\mathrm{W} \Delta \mathrm{N} 1$} & \multicolumn{2}{|c|}{$\mathrm{W} \Delta \mathrm{N} 2$} & \multicolumn{2}{|c|}{$\mathrm{W} \Delta \mathrm{Cdc} 25^{\mathrm{Mm}}$} & \multicolumn{2}{|c|}{ W $\Delta$ hSos 1} \\
\hline & $t_{\mathrm{d}}$ & BI & $t_{\mathrm{d}}$ & BI & $t_{\mathrm{d}}$ & BI & $t_{\mathrm{d}}$ & BI & $t_{\mathrm{d}}$ & BI \\
\hline SM & $2 \cdot 4 \pm 0 \cdot 1$ & $66 \pm 5$ & $2 \cdot 7 \pm 0 \cdot 1$ & $66 \pm 7$ & $2 \cdot 8 \pm 0 \cdot 1$ & $51 \pm 1$ & $2 \cdot 7 \pm 0 \cdot 2$ & $55 \pm 4$ & $2 \cdot 5 \pm 0 \cdot 2$ & $56 \pm 6$ \\
\hline YPE & $4 \cdot 5 \pm 0 \cdot 2$ & $52 \pm 5$ & $5 \cdot 3 \pm 0 \cdot 9$ & $58 \pm 4$ & $4 \cdot 5 \pm 0 \cdot 3$ & $41 \pm 3$ & $5 \cdot 9 \pm 0 \cdot 9$ & $35 \pm 4$ & $5 \cdot 8 \pm 0 \cdot 6$ & $36 \pm 3$ \\
\hline
\end{tabular}


(a)

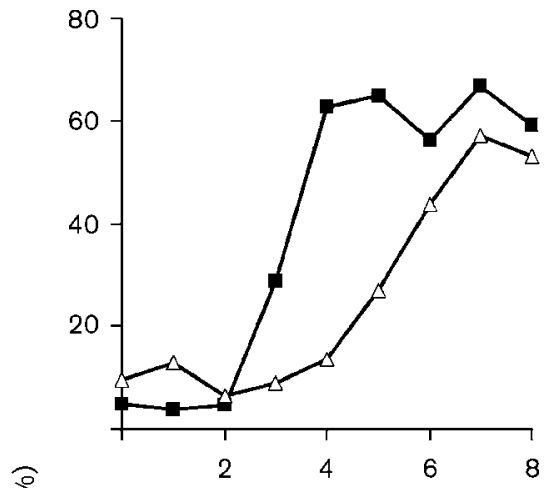

(c)

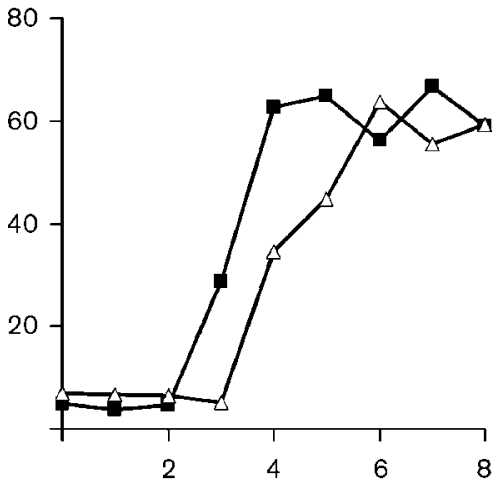

(b)

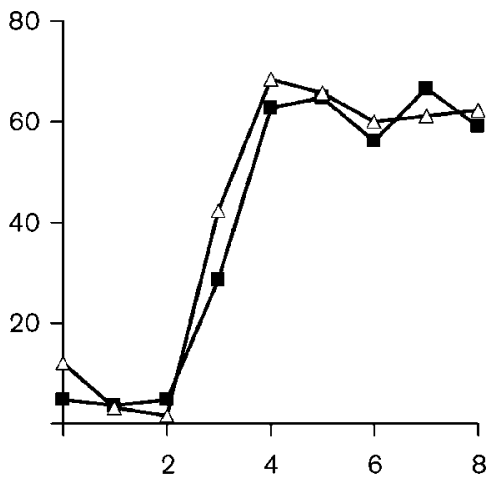

(d)

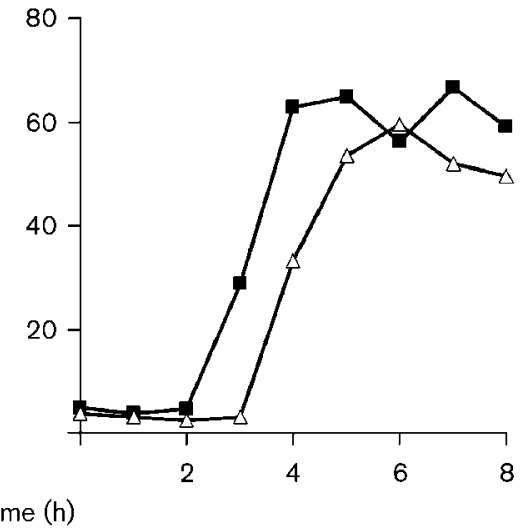

Fig. 2. $\mathrm{W} \Delta \mathrm{N} 1, \mathrm{~W} \Delta \mathrm{Cdc} 25^{\mathrm{Mm}}$ and $\mathrm{W} \Delta \mathrm{hSos} 1$ mutant strains showed a delay in growth recovery out of stationary phase. YPD cultures were incubated for 5 days at $24^{\circ} \mathrm{C}$. At time zero, the strains were diluted in fresh YPD medium, and resumption of growth was monitored by determining the $\mathrm{BI}$ as a function of time. (a) W303 ( $\boldsymbol{\square})$ and $\mathrm{W} \Delta \mathrm{N} 1$ mutant $(\triangle)$, (b) W303 (ם) and $\mathrm{W} \Delta \mathrm{N} 2$ mutant $(\triangle)$, (c) W303 (ם) and $\mathrm{W} \Delta \mathrm{Cdc} 25^{\mathrm{Mm}}$ mutant $(\triangle)$, (d) W303 (ם) and W $\mathrm{WhSos} 1(\triangle)$. showed higher $P_{\mathrm{t}}$ values, while the other mutants had smaller $P_{\mathrm{t}}$ values (Fig. $4 \mathrm{~b}$ ). Moreover, of the mutant strains, only $\mathrm{W} \Delta \mathrm{N} 1$ was like the wild type in being able to change its mean $P_{\mathrm{t}}$ in response to the nutritional conditions: the mutant strain showed a decrease of about $30 \%$ in its $P_{\mathrm{t}}$ in ethanol medium compared with glucose medium. In

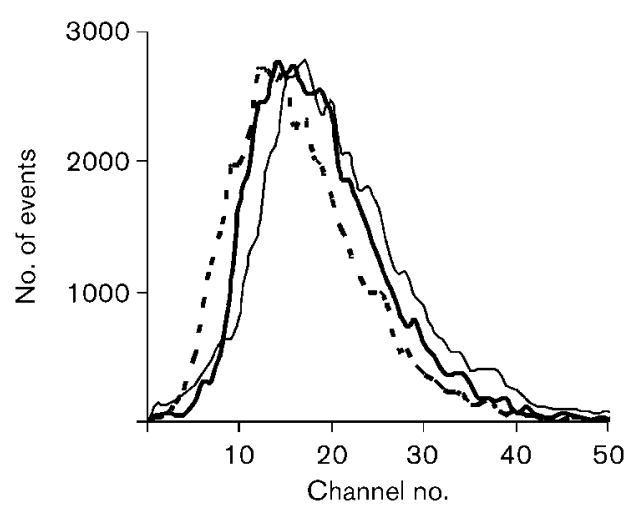

Fig. 3. Cell volume distributions of the wild-type and mutant strains during exponential growth in YPD medium. Cells were inoculated into YPD medium at $24^{\circ} \mathrm{C}$ to early exponential phase, and cell volume distributions were analysed as described in Methods. Strains: W303 (thick line), W $\Delta \mathrm{N1}$ (thin line), W $\Delta \mathrm{N} 2$ (dashed line). contrast, $\mathrm{W} \Delta \mathrm{N} 2, \mathrm{~W} \Delta \mathrm{Cdc} 25^{\mathrm{Mm}}$ and $\mathrm{W} \Delta \mathrm{hSos} 1$ showed smaller $P_{\mathrm{t}}$ values than the wild-type strain, and the values obtained for each strain were almost identical in the two conditions tested.

A possible cause for the different regulation of cell size and cellular protein content during exponential growth in different cultural conditions could be a defect in setting the $P_{\mathrm{s}}$ according to the environmental conditions. In fact, the critical size for entry into the S-phase constitutes the main nutrient-dependent control on the cell size, and is also dependent on the Ras/cAMP pathway (Baroni et al., 1989). $P_{\mathrm{s}}$ values were experimentally determined in exponentially growing populations of the different strains by using a biparametric FACS analysis of the mean $P_{\mathrm{t}}$ of gated early Sphase cells (Fig. 5), according to Coccetti et al. (2004). The results confirmed the hypothesis that the mutant strains $\mathrm{W} \Delta \mathrm{N} 2, \mathrm{~W} \Delta \mathrm{Cdc} 25^{\mathrm{Mm}}$ and $\mathrm{W} \Delta \mathrm{hSos} 1$ were defective in the nutrient-dependent regulation of the $P_{\mathrm{s}}$ threshold (Table 3 ).

Since the fraction of budded cells in the mutant strains was different from that of the wild-type, the cell distribution in the cell cycle phases was also expected to be different. FACS analysis of the DNA content distribution of the mutant strains during exponential growth on glucose (Fig. 6a) revealed that the $\mathrm{W} \Delta \mathrm{N} 2, \mathrm{~W} \Delta \mathrm{Cdc} 25^{\mathrm{Mm}}$ and $\mathrm{W} \Delta \mathrm{hSos} 1$ strains had a higher percentage of cells in $G_{1}$ phase than the wild-type strain. Moreover, while the number of $G_{1}$-phase 
(a)

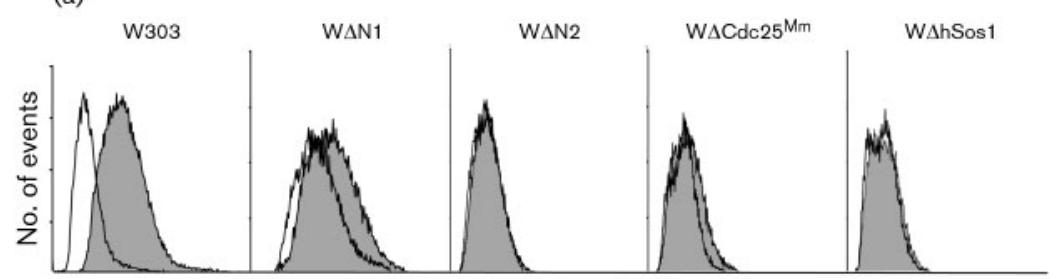

Protein content

(b)

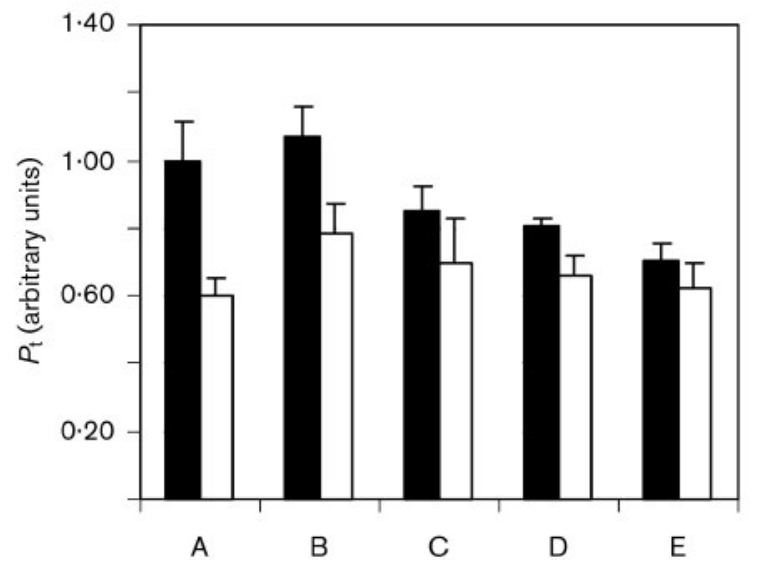

Fig. 4. Mutant strains show a defect in nutrient-dependent cell size regulation. (a) FACS analyses of the protein content distribution of strains growing in YPD medium (filled curve) and YPE medium (open curve). (b) Samples were taken from several cultures of each strain during exponential growth in YPD medium (black bars) and YPE medium (white bars), and these were analysed by FACS in order to obtain the protein content distribution. The $P_{\mathrm{t}}$ was calculated, and the mean values from at least four independent analyses were plotted. The error bars indicate SD. A, W303; B, W $\Delta \mathrm{N} 1$; C, W $\Delta \mathrm{N} 2 ; \mathrm{D}, \mathrm{W} \Delta \mathrm{Cdc} 25^{\mathrm{Mm}} ; \mathrm{E}, \mathrm{W} \Delta \mathrm{hSos} 1$.

cells in the wild-type strain almost doubled in ethanol medium compared with glucose medium, the mutant strains were completely unable to perform normal carbon source-dependent regulation of the cell cycle (Fig. 6a, b). $\mathrm{W} \Delta \mathrm{N} 1$ was the only strain to show a decrease in the fraction of cells in $G_{1}$ phase in comparison with the wild-type strain.

The defects in cell size modulation and growth recovery from $\mathrm{G}_{0}$ phase suggest that, in mutants, unregulated RasGEF activity could allow cells to grow, but some defects in transitory situations are to be expected. We analysed the behaviour of the mutant strains during a growth transition, namely a nutritional shift-up, where cells growing in ethanol medium were supplemented with glucose. In the wildtype strain, a transient increase in the length of $G_{1}$ phase occurs in this transition, in order for the strain to adapt to the new cultural conditions that require a higher $P_{\mathrm{s}}$ value than that required during growth on ethanol (Alberghina et al., 1998). This transition step can be monitored as a transient drop in BI, followed by recovery and adaptation to the typical BI obtained in glucose-containing medium.
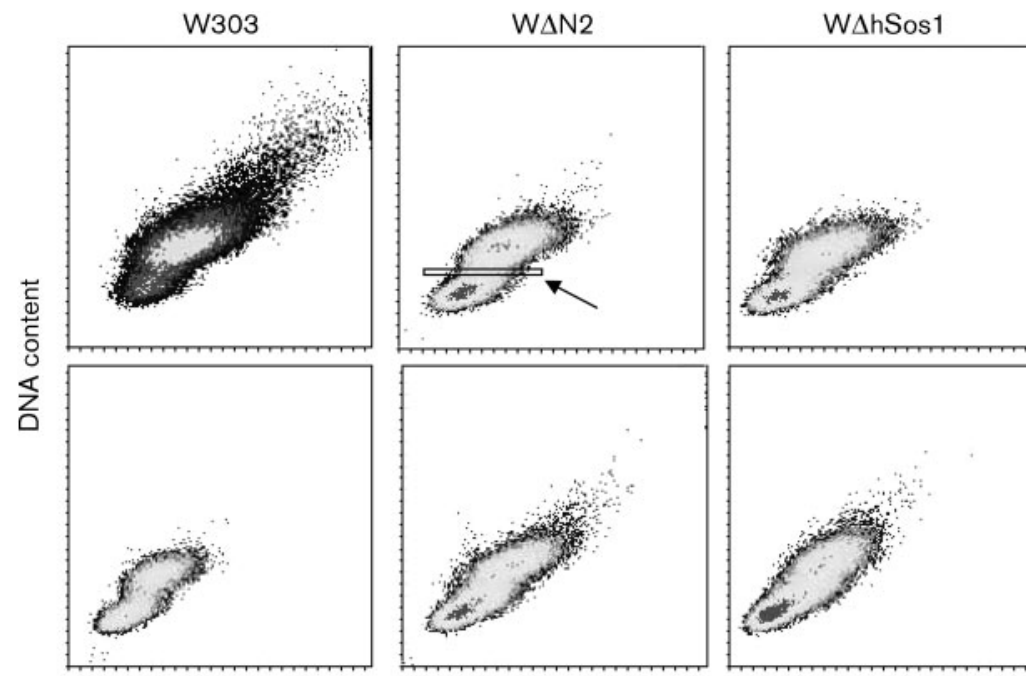

Protein content

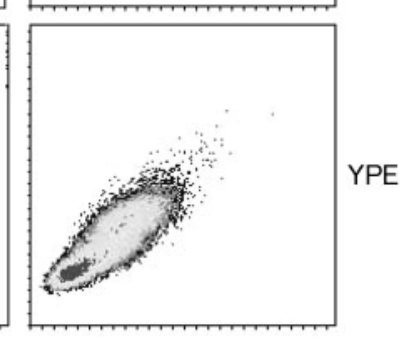

YPE
Fig. 5. Mutant strains show defects in nutrient-dependent modulation of the critical $P_{\mathrm{s}}$. Cells were collected during exponential growth in YPD or YPE medium, and analysed by FACS with biparametric staining. FITC fluorescence was plotted versus PI fluorescence as a density plot. The scales are in arbitrary units. The arrow indicates an example of a gated region used to evaluate the $P_{\mathrm{s}}$. 
Table 3. $P_{\mathrm{s}}$ values during exponential growth

$P_{\mathrm{s}}$ values were calculated as mean protein content of gated early S-phase cells on the density plots obtained by biparametric FACS analysis, and expressed as relative units with respect to the value for the wild-type in YPD medium.

\begin{tabular}{|lll|}
\hline Strain & YPD & YPE \\
\hline $\mathrm{W} 303$ & 1.00 & 0.66 \\
$\mathrm{~W} \Delta \mathrm{N} 1$ & 1.64 & 0.95 \\
$\mathrm{~W} \Delta \mathrm{N} 2$ & 0.70 & 0.72 \\
$\mathrm{~W} \Delta \mathrm{Cdc} 25^{\mathrm{Mm}}$ & 0.72 & 0.50 \\
$\mathrm{~W} \Delta \mathrm{hSos} 1$ & 0.61 & 0.62 \\
\hline
\end{tabular}

$\mathrm{W} \Delta \mathrm{N} 1$ showed normal control of this transition step, and the pattern of the BI during the nutritional shift-up was similar to that of the wild type (Fig. 7). In $\mathrm{W} \Delta \mathrm{N} 2$, $\mathrm{W} \Delta \mathrm{Cdc} 25^{\mathrm{Mm}}$ and $\mathrm{W} \Delta \mathrm{hSos} 1$, the BI did not show a decrease, but it steadily increased, leading to the values typical for growth on glucose.

\section{cdc25 mutants exhibit alterations in PKA activity}

An expected consequence of reduced or unregulated activity of the Cdc25 protein would be alteration of PKA activity. In order to verify this hypothesis, other phenotypic properties usually related to PKA activity were considered. The most immediate effect of abnormal PKA activity is sensitivity to heat shock: high activity correlates with high sensitivity to heat shock, and vice versa. Thus, heat-shock sensitivity of exponentially growing cells of the mutant strains was compared with the wild-type: $\mathrm{W} \Delta \mathrm{N} 1$ showed a high sensitivity to heat shock, whilst $\mathrm{W} \Delta \mathrm{N} 2, \mathrm{~W} \Delta \mathrm{Cdc} 25^{\mathrm{Mm}}$ and $\mathrm{W} \Delta \mathrm{hSos} 1$ were very resistant to heat-shock treatment (Fig. 8a).

In addition, an assay was performed to determine trehalase activity. The trehalase activity in S. cerevisiae is directly controlled by PKA phosphorylation (Wera et al., 1999). Consistent with the observations reported above, trehalase activity was higher in the $\mathrm{W} \Delta \mathrm{N} 1$ strain, and lower in the $\mathrm{W} \Delta \mathrm{N} 2, \mathrm{~W} \Delta \mathrm{Cdc} 25^{\mathrm{Mm}}$ and $\mathrm{W} \Delta \mathrm{hSos} 1$ strains, when compared with the wild type (Fig. 8b).

This led us to propose the hypothesis that in $\mathrm{W} \Delta \mathrm{N} 1$, the deletion of the N-terminal CDB motif could have resulted in greater accumulation of the GEF protein and/or an increase in GEF activity, leading to hyperactivation of the Ras/cAMP pathway. On the other hand, the heterologous GEFs are probably less efficient on yeast Ras. For $\mathrm{W} \Delta \mathrm{N} 2$, the phenotype observed was similar to the heterologous GEFproducing strains; the deletion in the CDC25 locus in the $\mathrm{W} \Delta \mathrm{N} 2$ strain resulted in a catalytic domain lacking a complete RasGEFN motif, which probably led to a basal activity of GEF that was reduced and not able to adapt to different conditions.

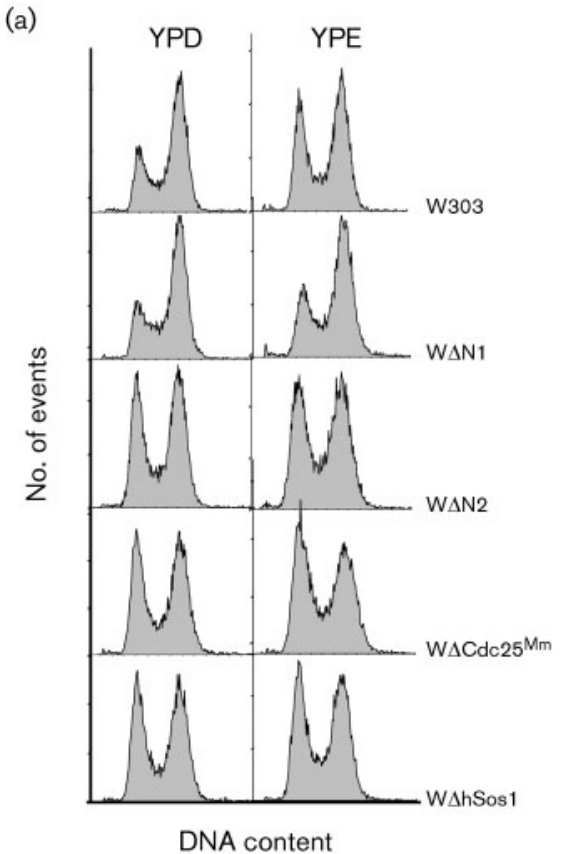

(b)

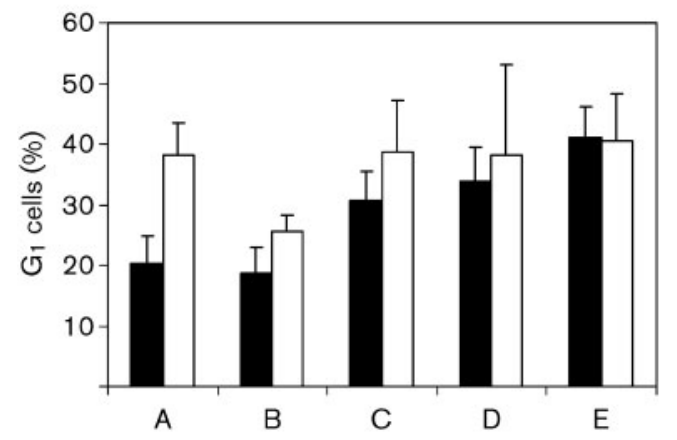

Fig. 6. (a) FACS analyses of DNA content distribution, as shown by $\mathrm{PI}$ staining, in strains growing in YPD medium at $24^{\circ} \mathrm{C}$. (b) Fraction of cells in $\mathrm{G}_{1}$ phase during growth in YPD medium (black bars) and YPE medium (white bars). Values are the means of at least three independent analyses. The error bars indicate SD. A, W303; B, W $\Delta \mathrm{N} 1$; C, W $\Delta \mathrm{N} 2 ; \mathrm{D}$, $\mathrm{W} \Delta \mathrm{Cdc} 25^{\mathrm{Mm}} ; \mathrm{E}, \mathrm{W} \Delta \mathrm{hSos} 1$.

\section{Overproduction of the SH3-containing $\mathrm{N}$-terminal fragment of Cdc25 rescues ira1 $\Delta$ strain growth and heat-stress sensitivity defects}

To further characterize the role played by the large $\mathrm{N}$ terminal region of $\mathrm{Cdc} 25$, we made several constructs that overproduced different fragments of this region (Fig. 9a). Since it has been reported that overproduction of the entire $\mathrm{N}$-terminal fragment is able to rescue the heat-shock sensitivity defect of the irals strain (Chen et al., 2000), we tested for this in constructs. The two larger fragments (encoding aa 1-1100 and 1-875) were able to rescue the heat-shock sensitivity of ira1s cells during exponential growth (data not shown) and in stationary phase (Fig. 9b). 


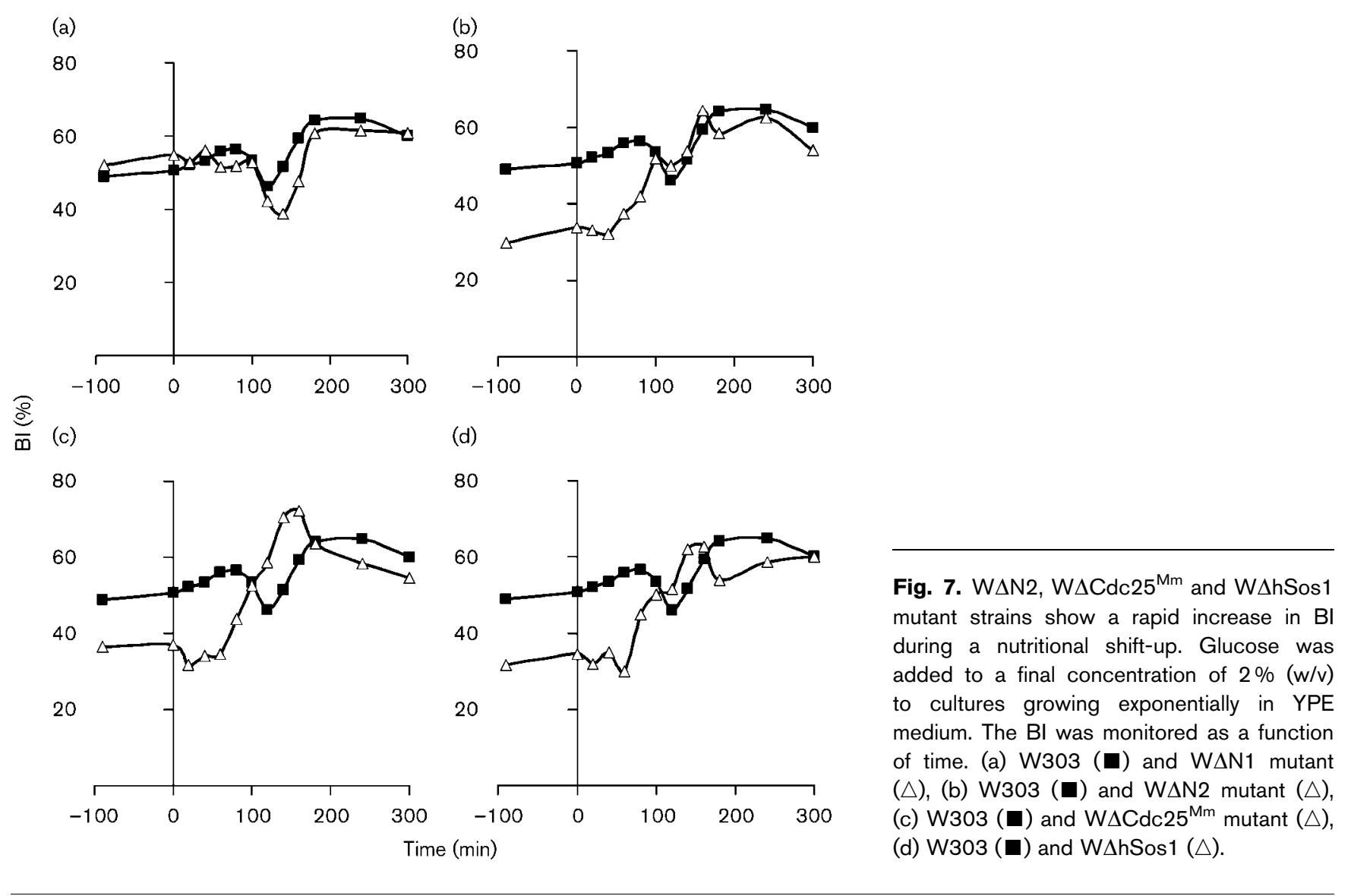

Moreover, overproduction of a smaller fragment (aa 8761100) was also able to rescue the heat-shock sensitivity of ira1 $\Delta$. Interestingly, the two larger fragments, containing the SH3 domain, not only conferred normal heat-shock resistance (Fig. 9b) to the ira $1 \Delta$ strain, but also higher viability to the mutant cells. In fact, the iral $\Delta$ strain producing either of the large fragments resumed growth quickly after being spotted from an exponentially growing population, and did not show any delay in recovery from stationary phase (data not shown). Overproduction of the smaller fragment (aa 876-1100) rescued the heat-shock sensitivity defect only; the cells still required a long incubation time to recover growth.

\section{Overproduction of the central region of Cdc25 confers heat-shock resistance to the wild-type strain}

Since it has been suggested that the ability of the N-terminal region to rescue ira $1 \Delta$ strain defects probably relies on an inhibitory effect of this domain on the Cdc25 protein itself (Chen et al., 2000), we looked for a similar effect in the wild-type strain when different fragments of this region were overproduced. In this background, none of the fragments tested affected the growth parameters for the wildtype strain during exponential growth on different growth media. In addition the fragments had no effect on recovery from stationary phase or nitrogen starvation, or on protein content or DNA distribution during exponential growth on different carbon sources (data not shown). The two larger fragments (encoding aa 1-1100 and 1-875) had no effect on heat-shock sensitivity. However, the central fragments, encoding aa 353-1100 and 876-1100, conferred a slightly stronger resistance to heat shock (data not shown), indicating that these fragments are able to interfere with PKA activity, and maybe with Cdc25 activity.

\section{DISCUSSION}

The Cdc25 protein is an exchange factor for Ras, and its activity is essential for growth of yeast cells. Despite the fact that Cdc25 was the first Ras GEF to be identified and characterized, it remains unclear whether its activity is regulated or not, and how the Cdc25/Ras/cAMP pathway transduces the signal originating from nutrients. Cdc25 is a large protein, and the essential exchange domain is restricted to the last $300 \mathrm{aa}$, but the presence of regulatory regions has never been clearly demonstrated. However, there is increasing evidence that the $\mathrm{Cdc} 25$ protein could dimerize, and possibly be part of a large complex with other elements of the pathway, i.e. adenylate cyclase and Ira proteins (Mintzer \& Field, 1999); in addition, Cdc25 has been found to interact with the heat-shock protein Ssal (Geymonat et al., 1998), and to be associated to 
(a)

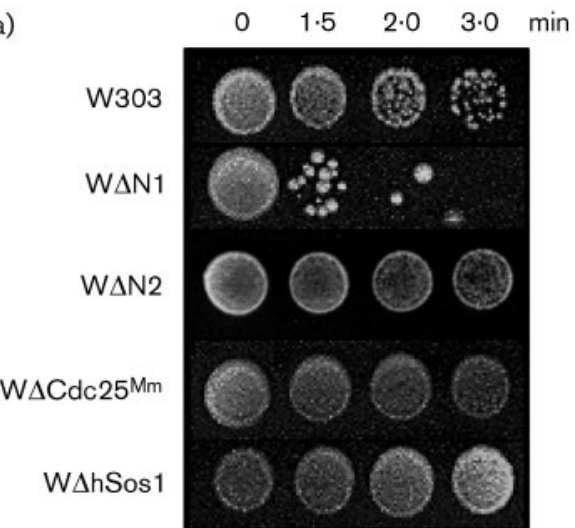

(b)

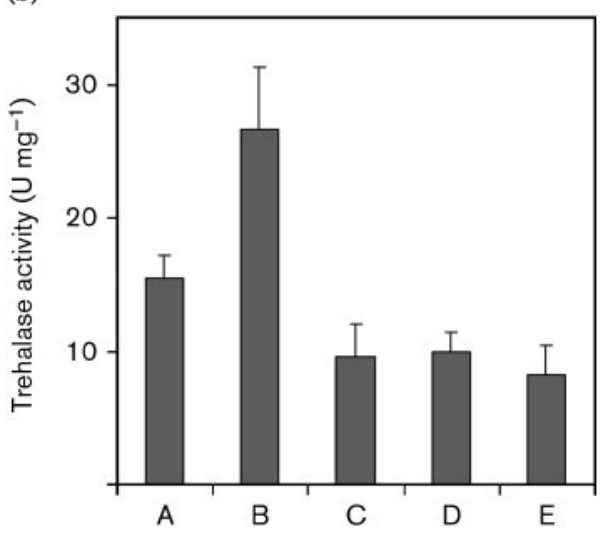

Fig. 8. Analyses of PKA-activity-related phenotypes in the mutant strains. (a) Heat-shock resistance in exponentially growing cells. Cells were incubated in YPD medium to exponential phase, and then exposed to heat shock at $51^{\circ} \mathrm{C}$ for $0,1.5,2$ and 3 min. Approximately $10^{4}$ cells were spotted on YPD agar, and incubated at $30^{\circ} \mathrm{C}$ for 3 days. (b) CDC25 mutants have different trehalase activity levels during the exponential growth phase. Samples of cells growing in YEP medium supplemented with $2 \%$ glycerol, at $30{ }^{\circ} \mathrm{C}$, were assayed for trehalase activity. The results shown are the means of at least three experiments. The error bars indicate SD. A, W303; B, W $\Delta N 1$; C, W $\Delta N 2 ; D$, $\mathrm{W} \Delta \mathrm{Cdc} 25^{\mathrm{Mm}} ; \mathrm{E}, \mathrm{W} \Delta \mathrm{hSos} 1$.

several different large protein complexes (Ho et al., 2002; Archambault et al., 2004).

Following several contradictory reports stating either the necessity (Munder \& Küntzel, 1989; Van Aelst et al., 1990; Schomerus et al., 1990; Van Aelst et al., 1991) or the dispensability (Goldberg et al., 1994) of Cdc25 for Ras activation upon glucose stimulation, $\mathrm{Cdc} 25$ has recently been identified as necessary for Ras2 GTP loading after glucose addition (Colombo et al., 2004). Furthermore, the $\mathrm{N}$-terminal domain of Cdc25 was initially proposed to be involved (Munder \& Küntzel, 1989; Schomerus et al., 1990) and not involved (Van Aelst et al., 1990) in the glucoseinduced cAMP response; however, recently, a negative regulatory role has been suggested for this region (Chen et al., 2000).

In order to investigate the role played by the putative regulatory domains of $\mathrm{Cdc} 25$ in the nutrient-sensing mechanism, we constructed several strains in which (1) Cdc25 was completely substituted by heterologous GEF domains, which were probably insensitive to any yeast regulatory mechanisms, but able to rescue the severe phenotype of CDC25 deletion; and (2) the N-terminal portion of Cdc25 was deleted, up to either the 906 a position or the 1146 aa position.

All the mutant strains showed growth parameters that were almost normal in both glucose- and ethanol-containing media (Fig. 1b, Table 2), and the strains were able to arrest in stationary phase or upon nitrogen starvation, producing a very low percentage of budded cells. In addition, all the mutant strains were able to grow in minimal medium containing acetate, glycerol or ethanol, showing that the Nterminal portion of Cdc25 was not required for growth on either glucose or non-fermentable carbon sources; these findings contradict a report by Munder et al. (1988). Moreover, our results indicate that the CDC25 requirement for growth can be substituted by RasGEF activity. In fact, our strains with a full deletion of the CDC25 gene, and producing the GEF domain of RasGRF1/Cdc $25^{\mathrm{Mm}}$ or human Sos1, grew as well as the wild-type, and were able to enter stationary phase as normal at the end of exponential growth.

However, all the mutants presented a delay in spore germination (Fig. 1a); this could not be explained by a growth defect, since the duplication time was not significantly different in the mutants strains, or by the slight delay observed in growth recovery from stationary phase (Fig. 2) or nitrogen starvation (data not shown). These findings clearly indicate that a complete $\mathrm{Cdc} 25$ protein is required for normal spore germination, and that it may also play a role in re-entry of the cell into the cell cycle.

Although all the mutant strains grew as well as the wildtype strain in all the conditions tested, nevertheless they presented some peculiar characteristics during exponential growth. Flow cytometry analysis demonstrated that $\mathrm{W} \Delta \mathrm{N} 2$, $\mathrm{W} \Delta \mathrm{Cdc} 25^{\mathrm{Mm}}$ and $\mathrm{W} \Delta \mathrm{hSos} 1$ were not able to modulate cell size and $P_{\mathrm{s}}$ in different nutrients. In fact, each of these strains had the same $P_{\mathrm{s}}$ in glucose and ethanol, whereas a wild-type strain normally modulates its $P_{\mathrm{s}}$ in a nutrientdependent manner (Table 3). In the mutants, this defect in $P_{s}$ modulation was accompanied by abnormal regulation of the cell cycle, as indicated by the increase of $G_{1}$-phase cells (Fig. 6b). The inability to regulate cell size in response to different nutrients is also in agreement with the behaviour of these mutant strains during a nutritional shift-up (Fig. 7). These defects have also been shown to be accompanied by phenotypic traits that are typical of reduced PKA activity (small cell volume, heat-shock resistance, and low trehalase activity) (Baroni et al., 1989; Mitsuzawa, 1994; Martegani 
(a)

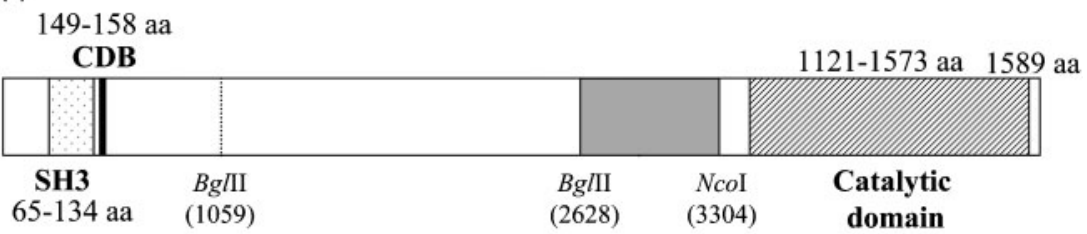

Construct

Protein fragment expressed

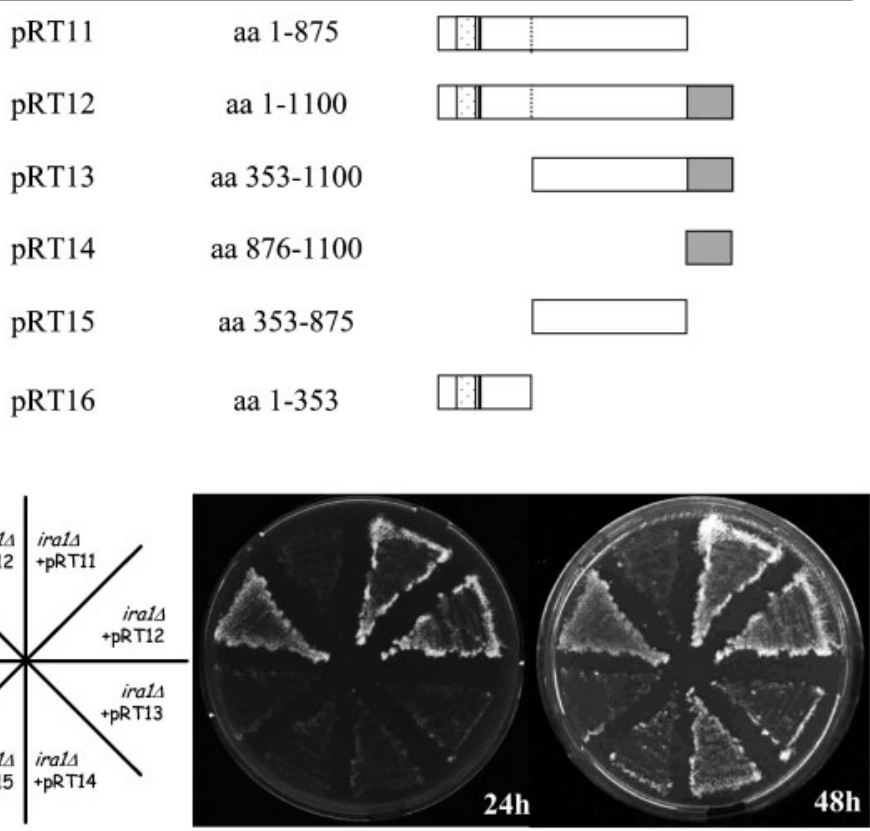

Fig. 9. Overproduction of Cdc25 N-terminal fragments confers higher heat-shock resistance. (a) Different fragments of the Cdc25 protein were overproduced in multicopy plasmids under the TPI promoter. (b) The heat-sensitive phenotype of the ira $1 \Delta$ strain was rescued mainly by overexpression of fragments encoding aa 1-875 and 1-1101, but also by the fragment encoding aa 875-1101. The ira1A strain was transformed with the plasmids indicated in the figure. Cells were subjected to heat shock, as described in Methods, and a photograph was taken of the culture after $24 \mathrm{~h}$ (left culture) and $48 \mathrm{~h}$ (right culture) incubation at $30^{\circ} \mathrm{C}$. et al., 1984; Wera et al., 1999). W $\Delta \mathrm{N} 1$ was able to maintain the ability to modulate cell size and $P_{\mathrm{s}}$ in response to nutrients, but, in all the conditions tested, it presented an increase in protein content compared with the wild-type, and showed several phenotypic traits consistent with a hyperactivated Ras/cAMP pathway (large volume, heatshock sensitivity and high trehalase activity).

These results indicate that the Cdc25 N-terminal region exerts a regulatory role, and is required for a normal glucosesensing mechanism, at least for the nutrient-dependent cell size regulation typical of normal yeast cells. In addition to this, the marked difference between $\mathrm{W} \Delta \mathrm{N} 2$ and $\mathrm{W} \Delta \mathrm{N} 1$ strains suggests that the region between aa 907 and 1146 could be important for exchange activity and nutrient sensing.

To further characterize the role played by the large $\mathrm{N}$ terminal region of $\mathrm{Cdc} 25$, several constructs were prepared that overproduced different fragments of this region. Overproduction of the fragments caused no visible alterations to growth, cell size and cell cycle regulation. A possible explanation for the weakness of the phenotypes generated by the overproduction of the N-terminal regions of Cdc25 could be that these domains need to be linked to an active RasGEF domain in order to exert their regulatory functions. Alternatively, perhaps the overproduced fragments could not properly localize in the specific cellular region (membranes?) where the whole Cdc25 protein is localized, and therefore were not able to interact properly with the endogenous Cdc25 GEF domain. The existence of an organized complex containing Cdc 25 could easily explain the weak dominant-negative effect of the large $\mathrm{N}$-terminal fragment spanning aa 1-875, which improved heat-shock resistance and survival of ira $1 \Delta$ mutants; this fragment spans important protein-protein interaction sites ( $\mathrm{SH} 3$ domain), and could destabilize the complex by competing for their binding sites. The aa 875-1100 region conferred an increase in heat-shock resistance in wild-type cells; this region does not contain any known domain, but it appears to be as well conserved as the catalytic domain in several fungal RasGEF proteins (data not shown). This finding reinforces the hypothesis that the aa $875-1100$ region could play an important role in the regulation of the GEF activity, as suggested by our results.

\section{ACKNOWLEDGEMENTS}

We thank Professor Johan Thevelein for helpful discussion and support in the trehalase assay, and P. Chardin and M. Vanoni for providing plasmids encoding hSosl. This work was partially supported by a FAR (ex-60\%) grant to E. M. 


\section{REFERENCES}

Alberghina, L., Smeraldi, C., Ranzi, B. M. \& Porro, D. (1998). Control by nutrients of growth and cell cycle progression in budding yeast, analyzed by double-tag flow cytometry. J Bacteriol 180, 3864-3872.

Anghileri, P., Branduardi, P., Sternieri, F., Monti, P., Visintin, R., Bevilacqua, A., Alberghina, L., Martegani, E. \& Baroni, M. D. (1999). Chromosome separation and exit from mitosis in budding yeast: dependence on growth revealed by cAMP-mediated inhibition. Exp Cell Res 250, 510-523.

Archambault, V., Chang, E. J., Drapkin, B. J., Cross, F. R., Chait, B. T. \& Rout, M. P. (2004). Targeted proteomic study of the cyclin-Cdk module. Mol Cell 18, 699-711.

Barbet, N. C., Schneider, U., Helliwell, S. B., Stansfield, I., Tuite, M. F. \& Hall, M. N. (1996). TOR controls translation initiation and early $\mathrm{G}_{1}$ progression in yeast. Mol Biol Cell 7, 25-42.

Baroni, M. D., Martegani, E., Monti, P. \& Alberghina, L. (1989). Cell size modulation by CDC25 and RAS2 genes in Saccharomyces cerevisiae. Mol Cell Biol 9, 2715-2723.

Boy-Marcotte, E., Ikonomi, P. \& Jacquet, M. (1996). SDC25, a dispensable Ras guanine nucleotide exchange factor of Saccharomyces cerevisiae differs from CDC25 by its regulation. Mol Cell Biol 7, 529-539.

Broek, D., Toda, T., Michaeli, T., Levin, L., Birchmeier, C., Zoller, M., Powers, S. \& Wigler, M. (1987). The S. cerevisiae CDC25 gene product regulates the RAS/adenylate cyclase pathway. Cell 48, 789-799.

Camonis, J. H., Kalékine, M., Gondré, B., Garreau, H., Boy-Marcotte, E. \& Jacquet, M. (1986). Characterization, cloning and sequence analysis of the $C D C 25$ gene which controls the cyclic AMP level of Saccharomyces cerevisiae. EMBO J 5, 375-380.

Chen, R. A., Michaeli, T., Van Aelst, L. \& Ballester, R. (2000). A role for the noncatalytic $\mathrm{N}$ terminus in the function of Cdc25, a Saccharomyces cerevisiae Ras-guanine nucleotide exchange factor. Genetics 154, 1473-1484.

Coccetti, P., Mauri, I., Alberghina, L., Martegani, E. \& Parmeggiani, A. (1995). The minimal active domain of the mouse ras exchange factor CDC25 ${ }^{\mathrm{Mm}}$. Biochem Biophys Res Commun 206, 253-259.

Coccetti, P., Rossi, R. L., Sternieri, F., Porro, D., Russo, G. L., di Fonzo, A., Magni, F., Vanoni, M. \& Alberghina, L. (2004). Mutations of the CK2 phosphorylation site of Sic1 affect cell size and SCdk kinase activity in Saccharomyces cerevisiae. Mol Microbiol 51, 447-460.

Colombo, S., Ma, P., Cauwenberg, L. \& 8 other authors (1998). Involvement of distinct G-proteins, Gpa2 and Ras, in glucose- and intracellular acidification-induced cAMP signalling in the yeast Saccharomyces cerevisiae. EMBO J 17, 3326-3341.

Colombo, S., Ronchetti, D., Thevelein, J. M., Winderickx, J. \& Martegani, E. (2004). Activation state of the Ras2 protein and glucose-induced signaling in Saccharomyces cerevisiae. J Biol Chem 279, 46715-46722.

Damak, F., Boy-Marcotte, E., Le-Roscouet, D., Guilbaud, R. \& Jacquet, M. (1991). SDC25, a CDC25-like gene which contains a Rasactivating domain and is a dispensable gene of Saccharomyces cerevisiae. Mol Cell Biol 11, 202-212.

Drebot, M. A., Barnes, C. A., Singer, R. A. \& Johnston, G. C. (1990). Genetic assessment of stationary phase for cells of the yeast Saccharomyces cerevisiae. J Bacteriol 172, 3584-3589.

Engelberg, D., Simchen, G. \& Levitzki, A. (1990). In vitro reconstitution of cdc25 regulated $S$. cerevisiae adenylyl cyclase and its kinetic properties. EMBO J 9, 641-651.

Geymonat, M., Wang, L., Garreau, H. \& Jacquet, M. (1998). Ssa1 chaperone interacts with the guanine nucleotide exchange factor of
Ras Cdc25p and controls the cAMP pathway in Saccharomyces cerevisiae. Mol Microbiol 30, 855-864.

Goldberg, D., Segal, M. \& Levitzki, A. (1994). Cdc25 is not the signal receiver for glucose induced cAMP response in $S$. cerevisiae. FEBS Lett 356, 249-254.

Gross, E., Goldberg, D. \& Levitski, A. (1992). Phosphorylation of the S. cerevisiae Cdc25 in response to glucose results in its dissociation from Ras. Nature 360, 762-765.

Gross, A., Winograd, S., Marbach, I. \& Levitzki, A. (1999). The Nterminal half of Cdc25 is essential for processing glucose signaling in Saccharomyces cerevisiae. Biochemistry 38, 13252-13262.

Hall, D. D., Markwardt, D. D., Parviz, F. \& Heideman, W. (1998). Regulation of the $\mathrm{Cln} 3 / \mathrm{Cdc} 28$ kinase by cAMP in Saccharomyces cerevisiae. EMBO J 17, 4370-4378.

Ho, Y., Gruhler, A., Heilbut, A. \& 43 other authors (2002). Systematic identification of protein complexes in Saccharomyces cerevisiae by mass spectrometry. Nature 415, 180-183.

Jones, S., Vignais, M. L. \& Broach, J. R. (1991). The CDC25 protein of Saccharomyces cerevisiae promotes exchange of guanine nucleotides bound to ras. Mol Cell Biol 11, 2641-2646.

Kaplon, T. \& Jacquet, M. (1995). The cellular content of Cdc25p, the Ras exchange factor in Saccharomyces cerevisiae, is regulated by destabilization through a cyclin destruction box. J Biol Chem 270, 20742-20747.

Lai, C. C., Bogusky, M., Broeck, D. \& Powers, S. (1993). Influence of guanine nucleotides on complex formation between Ras and Cdc25 proteins. Mol Cell Biol 13, 1345-1352.

Ma, P. S., Wera, S., Van Dijck, P. \& Thevelein, J. M. (1999). The PDE1encoded low-affinity phosphodiesterase in the yeast Saccharomyces cerevisiae has a specific function in controlling agonist-induced cAMP signaling. Mol Biol Cell 10, 91-104.

Martegani, E., Vanoni, M. \& Baroni, M. (1984). Macromolecular syntheses in the cell cycle mutant $c d c 25$ of budding yeast. Eur J Biochem 144, 205-210.

Martegani, E., Baroni, M. D., Frascotti, G. \& Alberghina, L. (1986). Molecular cloning and transcriptional analysis of the start gene CDC25 of Saccharomyces cerevisiae. EMBO J 5, 2363-2369.

Martegani, E., Vanoni, M., Zippel, R., Coccetti, P., Brambilla, R., Ferrari, C., Sturani, E. \& Alberghina, L. (1992). Cloning by functional complementation of a mouse cDNA encoding a homologue of CDC25, a Saccharomyces cerevisiae RAS activator. The EMBO J 11, 2151-2157.

Mintzer, K. A. \& Field, J. (1999). The SH3 domain of the Saccharomyces cerevisiae Cdc25p binds adenylyl cyclase and facilitates Ras regulation of cAMP signaling. Cell Signal 11, 127-135.

Mitsuzawa, H. (1994). Increases in cell size at START caused by hyperactivation of the cAMP pathway in Saccharomyces cerevisiae. Mol Gen Genet 243, 158-165.

Munder, T. \& Küntzel, H. (1989). Glucose-induced cAMP signaling in Saccharomyces cerevisiae is mediated by the CDC25 protein. FEBS Lett 242, 341-345.

Munder, T., Mink, M. \& Küntzel, H. (1988). Domains of the Saccharomyces cerevisiae CDC25 gene controlling mitosis and meiosis. Mol Gen Genet 214, 271-277.

Nakafuku, M., Obara, T., Kaibuchi, K. \& 7 other authors (1988). Isolation of a second yeast Saccharomyces cerevisiae gene (GPA2) coding for guanine nucleotide-binding regulatory protein: studies on its structure and possible functions. Proc Natl Acad Sci U S A 85, 1374-1378.

Plesset, J., Ludwig, J. R., Cox, B. S. \& McLaughlin, C. S. (1987). Effect of cell cycle position on thermotolerance in Saccharomyces cerevisiae. J Bacteriol 169, 779-784. 
Polymenis, M. \& Schmidt, E. V. (1997). Coupling cell division to cell growth by translational control of the $\mathrm{G}_{1}$ cyclin $\mathrm{Cln} 3$ in yeast. Genes Dev 11, 2522-2531.

Rolland, F., de Winde, J. H., Lemaire, K., Boles, E., Thevelein, J. M. \& Winderickx, J. (2000). Glucose-induced cAMP signalling in yeast requires both a G-protein coupled receptor system for extracellular glucose detection and a separable hexose kinase-dependent sensing process. Mol Microbiol 38, 348-358.

Rudoni, S., Colombo, S., Coccetti, P. \& Martegani, E. (2001). Role of guanine nucleotides in the regulation of the Ras/cAMP pathway in Saccharomyces cerevisiae. Biochim Biophys Acta 1538, 181-189.

Schomerus, C., Munder, T. \& Küntzel, H. (1990). Site-directed mutagenesis of the Saccharomyces cerevisiae CDC25 gene: effects on mitotic growth and cAMP signalling. Mol Gen Genet 223, 426-432.

Tamanoi, F. (1988). Yeast RAS genes. Biochim Biophys Acta 948, 1-15. Tanaka, K., Matsumoto, K. \& Toh-e, A. (1989). Ira1, an inhibitory regulator of the Ras-cyclic AMP pathway in Saccharomyces cerevisiae. Mol Cell Biol 9, 757-768.

Tanaka, K., Nakafuku, M., Satoh, T., Marshall, M. S., Gibbs, J. B., Matsumoto, K., Kaziro, Y. \& Toh-e, A. (1990a). S. cerevisiae genes IRA 1 and IRA 2 encode proteins that may be functionally equivalent to mammalian ras GTPase activating protein. Cell 60, 803-807.

Tanaka, K., Nakafuku, M., Tamanoi, F., Kaziro, Y., Matsumoto, K. \& Toh-e, A. (1990b). IRA2, a second gene in Saccharomyces cerevisiae that encodes a protein with a domain homologous to mammalian Ras GTP-ase activating protein. Mol Cell Biol 10, 4303-4313.

Thevelein, J. M. (1992). The Ras-adenylate cyclase pathway and cell cycle control in Saccharomyces cerevisiae. Antonie van Leeuwenhoek 62, 109-130.

Thevelein, J. M. \& de Winde, J. H. (1999). Novel sensing mechanisms and targets for the cAMP-protein kinase A pathway in the yeast Saccharomyces cerevisiae. Mol Microbiol 33, 904-918.

Thevelein, J. M., Cauwenberg, L., Colombo, S. \& 13 other authors (2000). Nutrient-induced signal transduction through the protein kinase A pathway and its role in the control of metabolism, stress resistance, and growth in yeast. Enzyme Microb Technol 26, 819-825.

Thomas, B. J. \& Rothstein, R. (1989). Elevated recombination rates in transcriptionally active DNA. Cell 56, 619-630.

Toda, T., Uno, I., Ishikawa, T. \& 7 other authors (1985). In yeast, Ras proteins are controlling elements of adenylate cyclase. Cell 40, 27-36.

Van Aelst, L., Boy-Marcotte, E., Camonis, J. H., Thevelein, J. M. \& Jacquet, M. (1990). The C-terminal part of the CDC25 gene product plays a key role in signal transduction in the glucose-induced modulation of cAMP level in Saccharomyces cerevisiae. Eur J Biochem 193, 675-680.

Van Aelst, L., Jans, A. W. \& Thevelein, J. M. (1991). Involvement of the CDC25 gene product in the signal transmission pathway of the glucose-induced RAS-mediated cAMP signal in the yeast Saccharomyces cerevisiae. J Gen Microbiol 137, 341-349.

Van Dijck, P., Colavizza, D., Smet, P. \& Thevelein, J. M. (1995). Differential importance of trehalose in stress resistance in fermenting and nonfermenting Saccharomyces cerevisiae cells. Appl Environ Microbiol 61, 109-115.

Vanoni, M., Vai, M., Popolo, L. \& Alberghina, L. (1983). Structural heterogeneity in populations of the budding yeast Saccharomyces cerevisiae. J Bacteriol 156, 1282-1291.

Vanoni, M., Vavassori, M., Frascotti, G., Martegani, E. \& Alberghina, L. (1990). Overexpression of the CDC25 gene, an upstream element of the ras/adenyl cyclase pathway in Saccharomyces cerevisiae, allows immunological identification and characterization of its gene product. Biochem Biophys Res Commun 172, 61-69.

Vernet, T., Dignard, D. \& Thomas, D. Y. (1987). A family of yeast expression vectors containing the phage $\mathrm{f} 1$ intergenic region. Gene 52, 225-233.

Wera, S., De Schrijver, E., Geyskens, I., Nwaka, S. \& Thevelein, J. M. (1999). Opposite roles of trehalase activity in heat-shock recovery and heat-shock survival in Saccharomyces cerevisiae. Biochem J 343, $621-626$. 